\title{
EFFECT OF THE ELECTROMAGNETIC COMPOUND FIELD ON THE GRAIN GROWTH AND WEAR RESISTANCE OF A Cu-Pb MONOTECTIC ALLOY
}

\author{
VPLIV SESTAVLJENIH PULZIRAJOČIH IN ELEKTROMAGNETNIH \\ POLJ NA RAST KRISTALNIH ZRN IN ODPORNOST Cu-Pb \\ ENO-EVTEKTIČNE ZLITINE PROTI OBRABI
}

\author{
Ziyang Li1, Ting Yu ${ }^{1}$, Dongxin Wang ${ }^{2}$, Guihong Geng1* \\ ${ }^{1}$ College of Materials Science and Engineering, North Minzu University, Yinchuan 750021, China \\ ${ }^{2}$ State Key Laboratory of Special Rare Metal Materials, Northwest Rare Metal Materials Research Institute Ningxia Co.Ltd, Yejin Road 119, \\ Shizuishan 753000, China
}

Prejem rokopisa - received: 2019-05-29; sprejem za objavo - accepted for publication: 2019-09-30

The $\mathrm{Cu}-37.4 w / \% \mathrm{~Pb}(\mathrm{Cu}-\mathrm{Pb})$ monotectic alloys were prepared under the normal solidification conditions and intense-pulse/ electromagnetic-compound fields. The $\mathrm{Cu}-\mathrm{Pb}$ monotectic alloy prepared under the normal solidification conditions was mainly composed of $\alpha-\mathrm{Cu}$ and severely segregated $\mathrm{Pb}$. With the compound fields applied, the segregation in the $\mathrm{Cu}-\mathrm{Pb}$ alloy fabrication process could be eliminated. The alloy was composed of $\alpha-\mathrm{Cu}$ and $\beta-\mathrm{Pb}$, and its crystals were lath-shaped with much finer grains compared to the one fabricated under the normal conditions. In addition, the crystal grains grew along the tangential direction of the pulse current radiationally, from the guiding center to the surrounding area, caused by the Lorentz-force-induced gyroscopic motion. From the friction and wear experiments, the $\mathrm{Cu}-\mathrm{Pb}$ alloy prepared by compound fields possesses a higher hardness, a lower friction coefficient and better wear resistance.

Keywords: intense pulse and electromagnetic compound fields, $\mathrm{Cu}-37.4 w / \% \mathrm{~Pb}, \mathrm{~Pb}$ monotectic alloy, grain growth, wear resistance

Avtorji članka so pripravili eno-evtektično zlitino $\mathrm{Cu}-37,4$ mas. \% $\mathrm{Pb}(\mathrm{Cu}-\mathrm{Pb}) \mathrm{v}$ normalnih pogojih strjevanja in v pogojih intenzivnih sestavljenih pulzirajočih elektromagnetnih polj. Eno-evtektična $\mathrm{Cu}-\mathrm{Pb}$ zlitina, pripravljena $\mathrm{v}$ normalnih pogojih strjevanja, je bila $\mathrm{v}$ glavnem sestavljena iz $\alpha-\mathrm{Cu}$ in močno segregiranega $\mathrm{Pb}$. Pri uporabi sestavljenih polj so odpravili segregacije $\mathrm{Pb}$ med izdelavo $\mathrm{Cu}-\mathrm{Pb}$ zlitine. Zlitina je bila sestavljena iz homogenih trdnih raztopin $\alpha$-Cu in $\beta$-Pb. Kristalna zrna so imela obliko letvic $\mathrm{z}$ mnogo bolj finimi kristalnimi zrni v primerjavi s tisto mikrostrukturo zlitine, ki je bila izdelana $\mathrm{v}$ normalnih pogojih strjevanja. Dodatno so ugotovili, da so kristalna zrna rasla vzdolž tangencialne smeri širjenja tokovnih pulzov s središčem vodenega preseka okolice, povzročenih z Lorenzovo silo induciranega žiroskopskega gibanja. Preizkusi trenja in obrabe so pokazali, da ima $\mathrm{Cu}-\mathrm{Pb}$ zlitina, pripravljena $\mathrm{v}$ sestavljenih poljih, večjo trdoto in manjši koeficient trenja ter boljšo odpornost proti obrabi.

Ključne besede: intenzivna sestavljena pulzirajoča in elektromagnetna polja, $\mathrm{Cu}-37,4$ mas. \% $\mathrm{Pb}$, eno-evtektična zlitina, rast kristalnih zrn, odpornost proti obrabi

\section{INTRODUCTION}

As one of the important metal materials in engineering, monotectic alloys have many unique properties and are widely used. ${ }^{1-7} \mathrm{Cu}-\mathrm{Pb}$ is a typical monotectic alloy, which has a high bearing capacity, a low friction coefficient and excellent wear/corrosion resistance. It has been widely used in thermal conduction and wearresistant materials. However, the phase separation easily occurs during alloy preparation with normal solidification due to the considerably large difference between the density of $\mathrm{Cu}$ and $\mathrm{Pb}$. Thus strong segregation of the secondary phase and obvious stratification phenomenon exist in the $\mathrm{Cu}-\mathrm{Pb}$ monotectic alloy, which results in substantial deterioration.

*Corresponding author's e-mail

gengguihong@163.com (Guihong Geng)
Based on an understanding of biphasic separation mechanism, many new methods have been attempted to prepare monotectic alloys with excellent properties. Abramov prepared $\mathrm{Al}-\mathrm{Pb}$ anti-friction alloys by casting in a microgravity field. It was found that the aluminum matrix produced a uniform distribution and possesses high anti-friction properties. ${ }^{8}$ E. G. Wang and L. Zhang, ${ }^{9}$ made research on the solidification structure of a $\mathrm{Cu}-80 \mathrm{wt} \% \mathrm{~Pb}$ alloy, which was investigated under four different experimental conditions. The result showed that a magnetic field has a remarkable effect on restraining the gravity segregation of the $\mathrm{Cu}-\mathrm{Pb}$ alloy. Y. Liu analyzed the liquid phase separating mechanism of immiscible alloys and summarized the synthetic techniques of homogeneous immiscible alloys. ${ }^{10} \mathrm{~W}$. X. Hao ${ }^{11}$ prepared $\mathrm{Cu}-37.4 w / \% \mathrm{~Pb}$ alloys in the highly undercooling conditions. It was found that the grain of the alloy was gradually refined with the increase of the cooling rate and the alloy showed a good anti-friction property. M. 




Figure 1: Schematic diagram of our own designed equipment

Zhu ${ }^{12}$ prepared $\mathrm{Al}-\mathrm{Pb}-\mathrm{Cu}$ alloy by mechanical alloying (MA), the result revealed the strength of the alloy was increased owing to solid-solution strengthening and precipitation strengthening. In addition, unidirectional solidification, stirring casting and rapid solidification are also widely used in the preparation of monotectic alloys. ${ }^{10-15}$

In this paper the $\mathrm{Cu}-37.4 w / \% \mathrm{~Pb}(\mathrm{Cu}-\mathrm{Pb})$ monotectic alloy was prepared by the intense pulse and electromagnetic compound fields, where the undercooling and magnetostriction influence on the $\mathrm{Cu}-\mathrm{Pb}$ monotectic alloy grain growth was investigated. Furthermore, the influence of the compound fields on the composition separation of the $\mathrm{Cu}-\mathrm{Pb}$ monotectic alloy was analyzed and described. The refinement mechanism of the crystals under the compound fields was thoroughly investigated and explained.

\section{EXPERIMENTAL PART}

The monotectic alloy ingots with the composition of $\mathrm{Cu}-37.4 w / \% \mathrm{~Pb}$ were prepared by a mixture of pure metals with a purity of $99.99 w / \%$. The ingot preparations were carried out in a simulated microgravity equipment that designed by us. Figure $\mathbf{1}$ is a schematic diagram of the device. ${ }^{16}$ The temperature of the device was monitored by an infrared thermometer. The heating curve of the fabrication process was exemplified in Figure 2. The ingot prepared by normal solidification was heated to $1200{ }^{\circ} \mathrm{C}$ firstly, and then kept at $1200{ }^{\circ} \mathrm{C}$ for $60 \mathrm{~min}$, followed by cooling to the room temperature. The ingot prepared from the intense pulse and electromagnetic compound fields had the same heating process. After the temperature was held for $60 \mathrm{~min}$, an electromagnetic field $(0.5 \mathrm{~T})$ was applied for $2 \mathrm{~min}$. In the cooling process at a temperature interval of $1200{ }^{\circ} \mathrm{C}$ to
$955{ }^{\circ} \mathrm{C}$, an intense pulse (with a width of $20 \mu \mathrm{s}$, frequency of $30 \mathrm{~Hz}$ and peak current of 1800A) was employed. After that, the $\mathrm{Cu}-\mathrm{Pb}$ ingot was cooled to room temperature and cut into small pieces for the microstructure and properties investigation.

The microstructures and compositions of the samples were investigated by scanning electron microscopy (SEM, SS-550 ISSEM), energy-dispersive spectroscopy (EDS, PHOENIX EDAX-2000) and X-ray diffraction $(\mathrm{XRD}, 6000 \mathrm{X})$. Friction and wear experiments were performed on a HT-1000 friction-abrasion testing machine for $30 \mathrm{~min}$ at room temperature. The friction radius is $3 \mathrm{~mm}$, the load is $5 \mathrm{~N}$, and the rotation speed is $390 \mathrm{~min}^{-1}$, samples were ground on GCr15 without lubrication. The microhardness tests were performed under a load of $4.9 \mathrm{~N}$ and a dwell time of $10 \mathrm{~s}$.

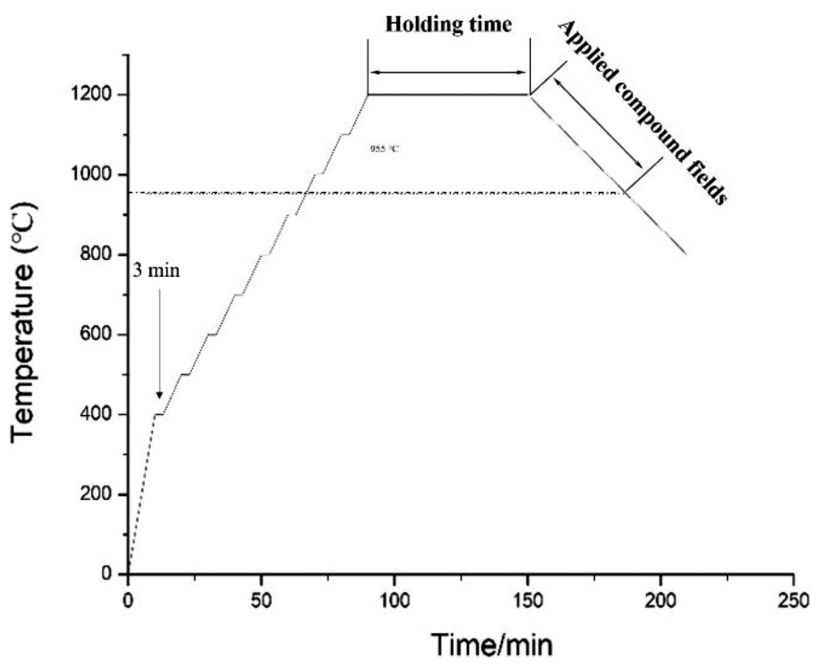

Figure 2: Curve of heating temperature 

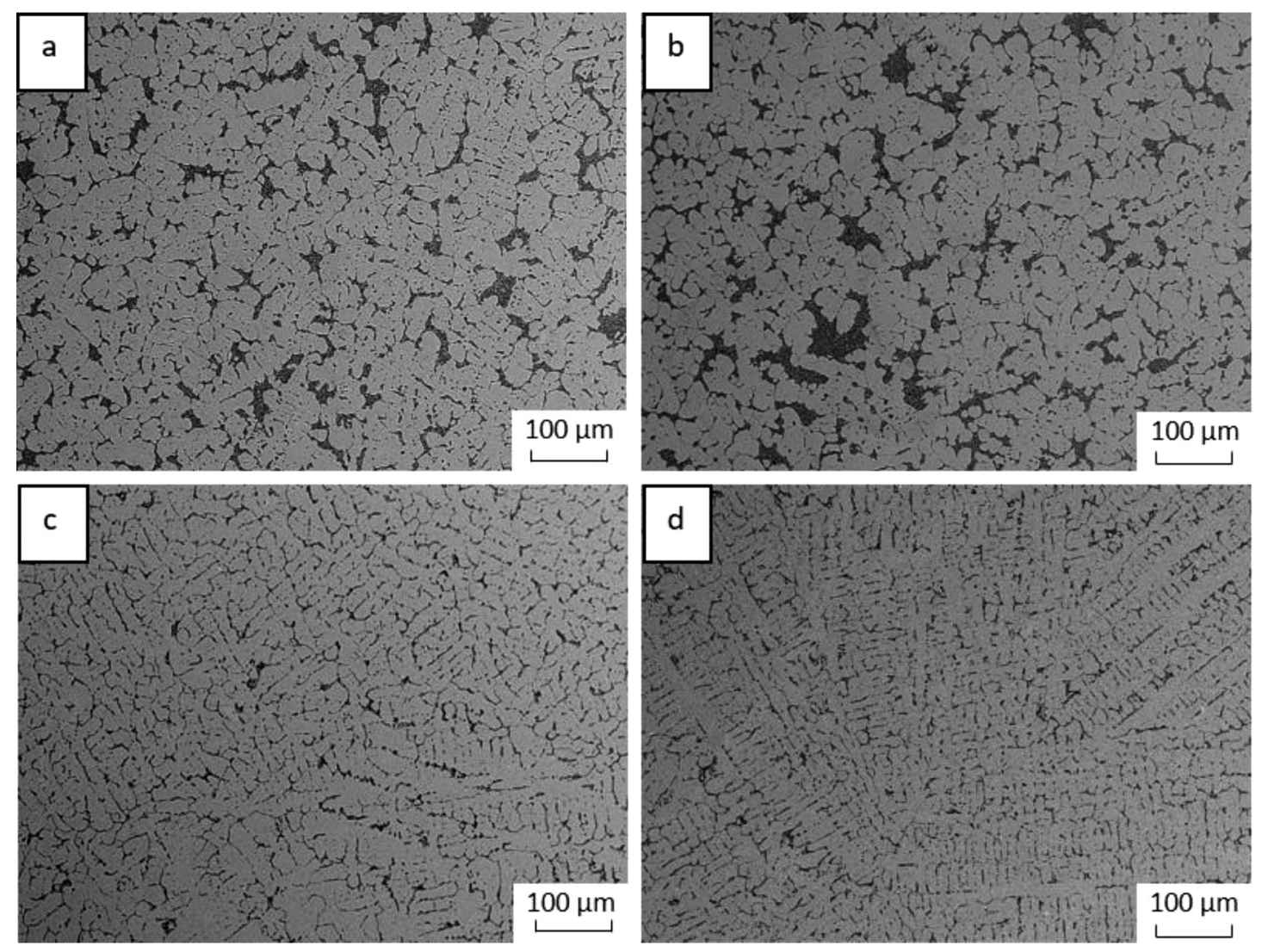

Figure 3: $\mathrm{SEM}$ of $\mathrm{Cu}-37.4 w / \% \mathrm{~Pb}, \mathrm{Cu}-\mathrm{Pb}$ alloy prepared under normal solidification (a and $\mathrm{b})$ and complex fields (c and d). Transverse (a and c) and vertical ( $c$ and $\mathrm{d}$ ) are the directions along and vertical to the current, respectively
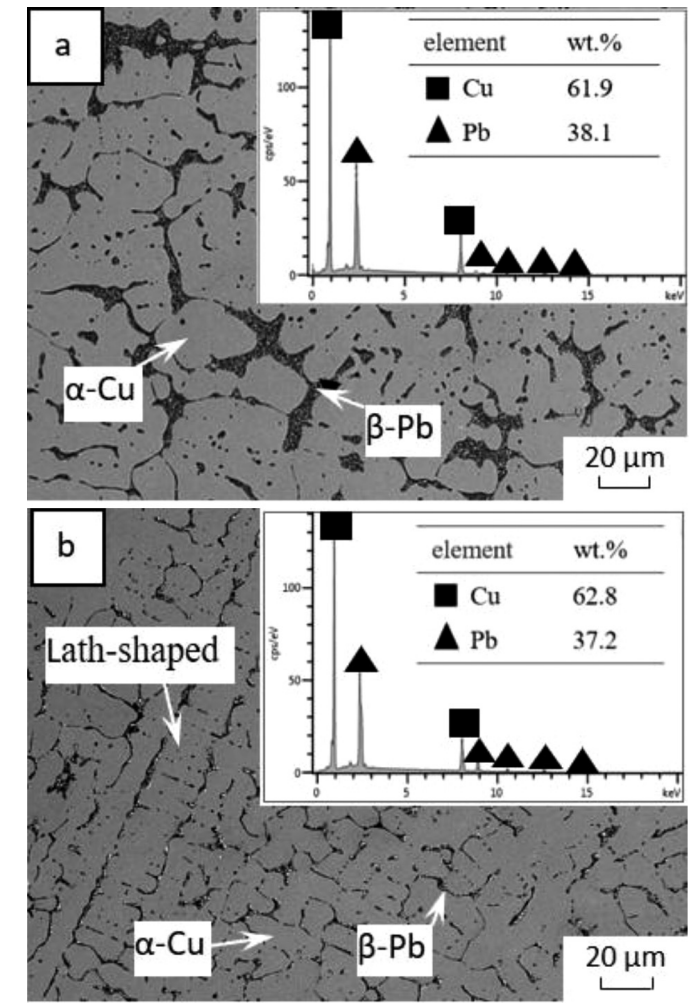

Figure 4: Energy-dispersive spectroscopy (EDS) images of $\mathrm{Cu}-37.4 w / \% \mathrm{~Pb}$ monotectic alloy, $\mathrm{Cu}-\mathrm{Pb}$ alloy prepared under normal solidification condition (a) and complex fields (b)

\section{RESULTS}

\subsection{Microstructure of $\mathrm{Cu}-37.4 w / \% \mathrm{~Pb}$ monotectic alloy}

SEM images of the $\mathrm{Cu}-\mathrm{Pb}$ monotectic alloy prepared under normal solidification and complex fields are shown in Figure 3, the EDS are shown in Figure 4 and the XRD patterns of the alloy are shown in Figure 5.

As shown in Figures $\mathbf{4}$ and $\mathbf{5}$, a gray matrix denoted as $\alpha$-Cu could be observed, and the $\mathrm{Pb}$-phase could be

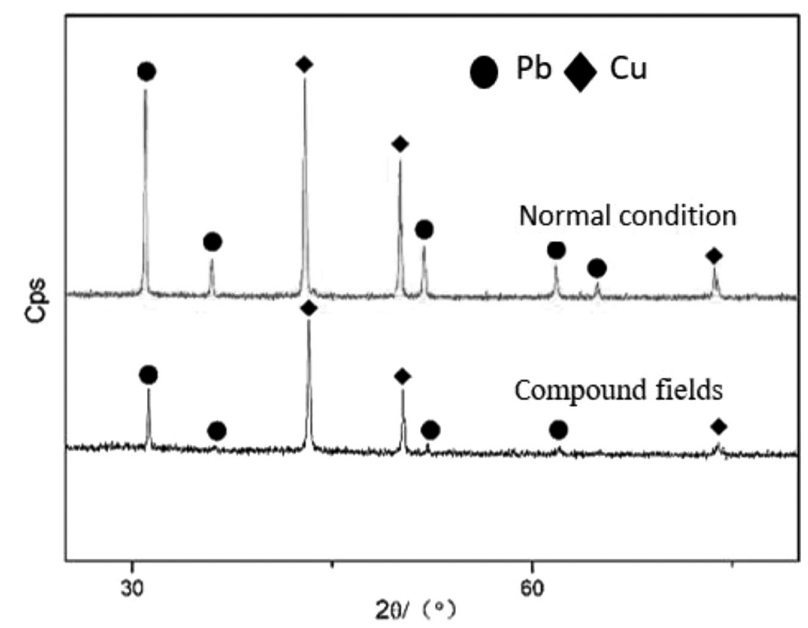

Figure 5: $\mathrm{XRD}$ patterns of the $\mathrm{Cu}-37.4 w / \% \mathrm{~Pb}$ monotectic alloy prepared under normal solidification conditions and complex fields 


\section{Z. LI et al.: EFFECT OF THE ELECTROMAGNETIC COMPOUND FIELD ON THE GRAIN GROWTH ...}

distinguished at the crystal grain boundaries of the $\mathrm{Cu}$. The $\mathrm{Cu}-\mathrm{Pb}$ alloy prepared by normal solidification is mainly composed of $\alpha-\mathrm{Cu}$ and $\mathrm{Pb}$ with large crystal grains, in which the messily distributed $\mathrm{Pb}$ agglomerates on the matrix (Figure 3a and $\mathbf{3 b}$ ). With the help of the intense pulse and electromagnetic compound fields, the segregation almost disappears, as shown in Figure 3c and 3d. The black-grid structure along the crystal grain boundary becomes lath-shaped, and the refined crystal grains are achieved. It is clear that the crystal grains radiationally grow from the guiding center to the surrounding area (Figure 3d).

\subsection{Microhardness}

In the microhardness testing, 7 points were randomly selected for each sample. The results are presented in Table 1 (MAX T-L is the maximum difference).

As shown in Table 1, the average microhardness of $\mathrm{Cu}-\mathrm{Pb}$ under normal solidification is $\mathrm{HV}_{4.9} 35.47$. Its microhardness is considerably increased to $\mathrm{HV}_{4.9} 58.50$ due to the treatment by complex fields. The MAX T-L is large and the hardness is not uniform.

Table 1: Microhardness test table of $\mathrm{Cu}-37.4 w / \% \mathrm{~Pb}$ (HV); MAX T-L is the maximum difference

\begin{tabular}{|c|c|c|}
\hline Test point & $\begin{array}{c}\text { Normal } \\
\text { solidification }\end{array}$ & Complex fields \\
\hline 1 & 37.88 & 57.10 \\
\hline 2 & 36.24 & 57.07 \\
\hline 3 & 35.65 & 61.24 \\
\hline 4 & 42.29 & 57.49 \\
\hline 5 & 33.80 & 55.30 \\
\hline 6 & 35.84 & 63.37 \\
\hline 7 & 26.58 & 57.90 \\
\hline Average & 35.47 & 58.50 \\
\hline MAX T-L & 15.71 & 8.07 \\
\hline
\end{tabular}

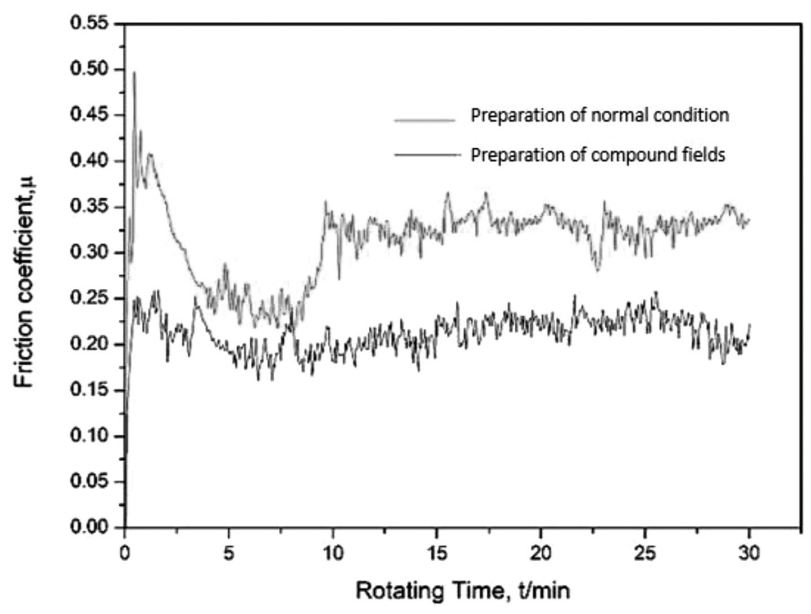

Figure 6: Friction curves of the $\mathrm{Cu}-37.4 w / \% \mathrm{~Pb}$ monotectic alloy

\subsection{Friction and wear properties}

The friction and wear properties of the alloy were evaluated using the friction coefficient. The variation of the friction coefficient with the time is shown in Figure 6. The average friction of coefficient and the weight loss (30 min) of the alloy are shown in Table 2.

It is obvious that the friction coefficient of the $\mathrm{Cu}-\mathrm{Pb}$ alloy using normal solidification is stable after 10 minutes of testing, and its variation amplitude is larger compared with the one assisted by the complex field. Its average friction coefficient is 0.315 , and the wear loss is $6.623 \mathrm{mg}$. The friction coefficient of the alloy prepared with complex fields needs 7 minutes for stabilization. Its average friction coefficient is 0.213 , and the weight loss is substantially decreased by $51.5 \%$.

Table 2: Friction coefficient and weight loss of $\mathrm{Cu}-\mathrm{Pb}$ alloy

\begin{tabular}{|c|c|c|}
\hline Test sample & $\begin{array}{c}\text { Normal } \\
\text { solidification }\end{array}$ & $\begin{array}{c}\text { Complex } \\
\text { fields }\end{array}$ \\
\hline Average friction coefficient & 0.315 & 0.213 \\
\hline Abrasion loss (mg) & 6.623 & 3.210 \\
\hline
\end{tabular}

\section{DISCUSSION}

The $\mathrm{Cu}-\mathrm{Pb}$ alloy is a kind of monotectic alloy. When the temperature of the $\mathrm{Cu}-\mathrm{Pb}$ alloy is higher than the liquidus temperature, the liquid phase is completely miscible. As the liquid is cooled below to the liquidus temperature, the liquid phase separates into two phases $\left(L_{1}+L_{2}\right)$. When the $\mathrm{Cu}-\mathrm{Pb}$ monotectic alloy is cooled below to the monotectic reaction temperature of $955^{\circ} \mathrm{C}$, a monotectic reaction occurs:

$$
L_{1} \rightarrow \alpha(\mathrm{Cu})+L_{2}
$$

The liquid phase $L_{1}$ decomposes into a solid phase $\alpha$ $(\mathrm{Cu})$ and a liquid phase $L_{2}$. The phase $L_{2}$ precipitates the surrounding $\alpha(\mathrm{Cu})$. As the temperature continues to decline, the redistribution of the solute occurs in both $\alpha$ $(\mathrm{Cu})$ and $L_{2}$ phases. As a result, the rich-solute phase $L_{2}$ solidifies into a Pb-rich phase. As it is cooled to the eutectic temperature, the eutectic reaction occurs in the remaining liquid phase $L_{2}$, forming two solid phases of $\mathrm{Cu}$ and $\mathrm{Pb}$.

$$
L_{2} \rightarrow \mathrm{Cu}+\mathrm{Pb}
$$

Under normal solidification conditions the density difference between $L_{1}$ and $L_{2}$ in the $\mathrm{Cu}-\mathrm{Pb}$ alloy is large, which leads to the phase stratification due to the Stockes deposition effect. As a result, severe phase segregation occurs due to gravity (Figure $\mathbf{3 a}$ and $\mathbf{3 b}$ ).

Without the electromagnetic field, the thermal movement of ions is random and arbitrary. As an electromagnetic field is applied (Figure 7), the velocity $V$ of an ion is decomposed into two velocity components, i.e., perpendicular $V_{\perp}$ and parallel $V_{\|}$. Along the vertical motion direction, the Lorentz force is produced because of the 


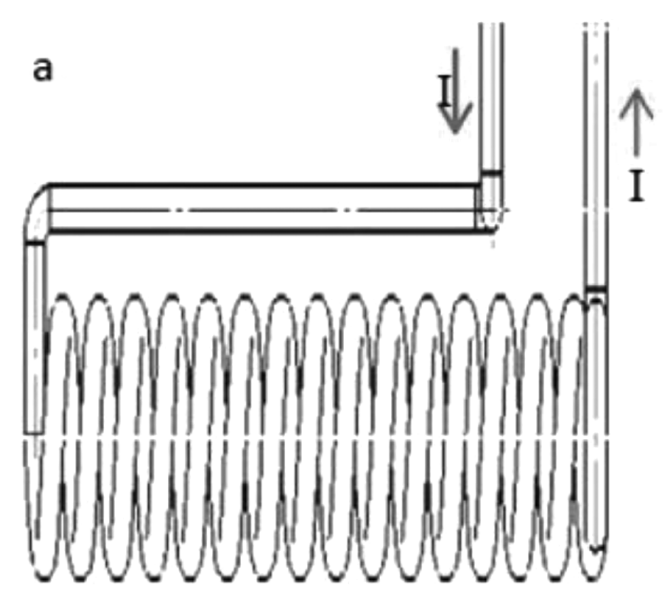

Figure 7: Magnetic effect under an energized coil

interaction between an ion with a charge of $q$ and the electromagnetic field $\mathrm{f}$ :

$$
\overrightarrow{\mathbf{f}}=q \vec{v}_{1} \times \overrightarrow{\mathbf{B}}
$$

The velocity $V_{\perp}$, without changes of the magnitude and the direction, is perpendicular to the Lorentz force. As a result, the ions rotate around the electromagnetic line with the load of the Lorentz force. Meanwhile, the force of $V_{\|}$results in the movement of the ions along the electromagnetic line. The influence of the electromagnetic field on a charged particle can be described by a motion Equation (4):

$$
m \ddot{v}=q(\dot{v} \times B)
$$

Where $m$ is the mass of the charged particle, the Larmor circle transformation of Equation ${ }^{17,18}$ (4) is as follows in ${ }^{19}$ :

$$
\begin{aligned}
& {\left[x-\left(x_{0}-\frac{v_{\perp}}{\omega_{\mathrm{c}}} \sin \alpha\right)\right]^{2}\left[y-\left(y_{0}-\frac{v_{\perp}}{\omega_{\mathrm{c}}} \cos \alpha\right)\right]^{2}=} \\
& =\frac{v_{\perp}^{2}}{\omega_{\mathrm{c}}^{2}}=\frac{m^{2} v_{\perp}^{2}}{q^{2} B^{2}}
\end{aligned}
$$

The particles move in the plane $z=v \| t+z_{0}$.

Larmor's center is:

$$
\left(x_{0}-\frac{v_{\perp}}{\omega_{\mathrm{c}}} \sin \alpha, y_{0}-\frac{v_{\perp}}{\omega_{\mathrm{c}}} \cos \alpha\right)
$$

and the guiding center is:

$$
r_{\mathrm{c}}=\left(x_{0}-\frac{v_{\perp}}{\omega_{\mathrm{c}}} \sin \alpha, y_{0}-\frac{v_{\perp}}{\omega_{\mathrm{c}}} \cos \alpha, v \| t+z_{0}\right)
$$

and the Larmor radius is:

$$
r_{c}=\frac{v_{\perp}}{\omega_{c}}=\frac{m v_{\perp}}{|q| B}
$$

The values of $x_{0}, y_{0}, z_{0}, V_{\perp}, V_{\|}$and $\alpha$ are determined by the initial conditions. The Larmor radius, denoted as

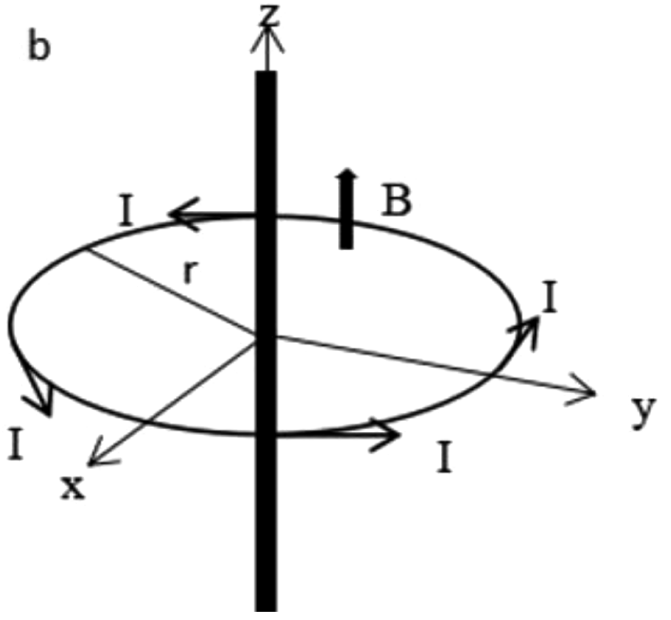

the cyclotron radius, is proportional to the ion mass and inversely proportional to the charge of $q$. Since the mass and charges of $\mathrm{Cu}^{+}$and $\mathrm{Pb}^{+4}$ are considerably different, the size of their Larmor radii is obviously different. The relative movement of the solute particles under the action of the electromagnetic field enhances the diffusion of the solute $\mathrm{Pb}$ in $\mathrm{Cu}$, which results in an increase of the solubility of $\mathrm{Pb}$ in $\mathrm{Cu}$, and therefore, the suppression of the segregation (Figure 3c and $\mathbf{3 d}$ ). In the vertical direction of the pulse current, particles rotate in the plane

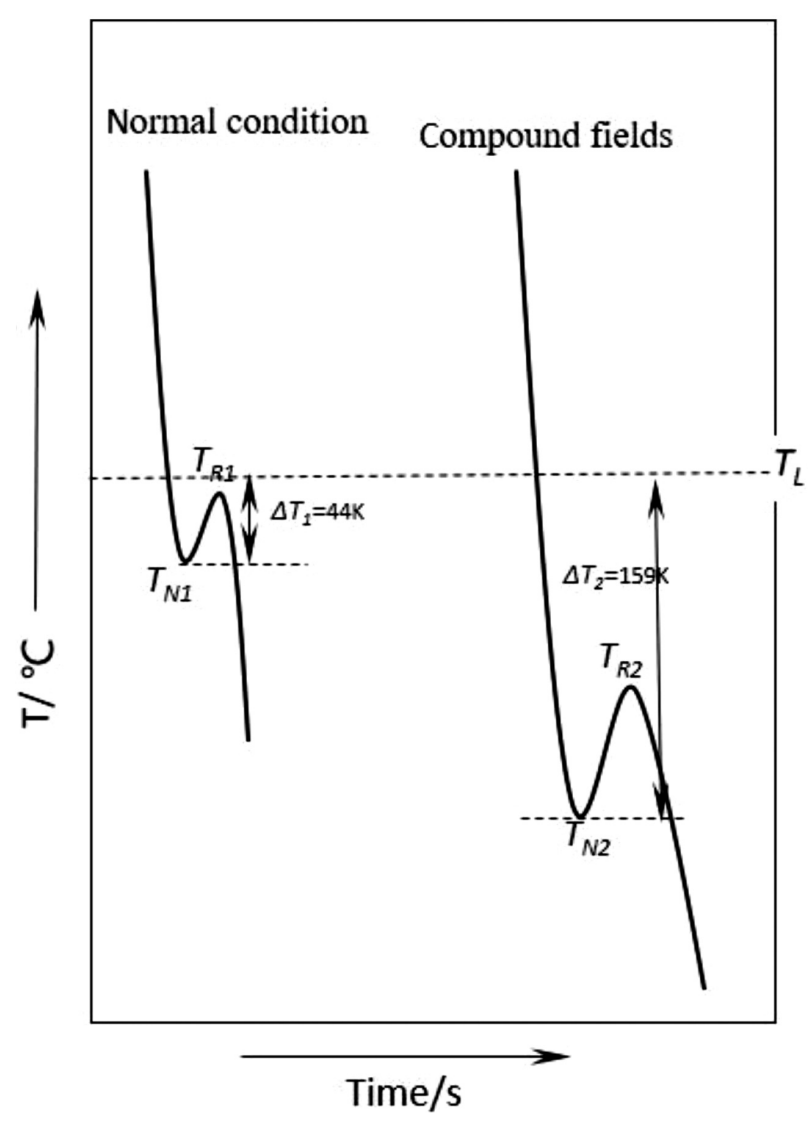

Figure 8: Cooling curves of $\mathrm{Cu}-37.4 w / \% \mathrm{~Pb}$ monotectic alloys 
$z=v \| t+z_{0}$, where the crystal grains radiationally grow from the guiding center to the surrounding area (Figure 3d). In addition, the melt is repeatedly compressed via an electromagnetic force according to the magnetostrictive effect, which results in the rapid disappearance of the overheating in the melt. ${ }^{19}$ Thus the degree of undercooling is substantially increased. Meanwhile, the growth of the crystal grains is suppressed, and the dendrites are broken. As a result, the crystal grains are refined and they become lath-shaped.

According to the solidification theory, nucleation occurs in a melt under a certain condition of undercooling to overcome the interface energy between the liquid and the solid phases. The intense pulse current can effectively increase the undercooling degree of the melt during solidification, which enhances the nucleation. As a pulse current is applied into a melt, the influence of the current on the undercooling degree can be expressed as,

$$
\Delta T=k J_{0}^{2} \varepsilon \pi r^{2} \Delta T_{m} C^{-1}
$$

where $\Delta T$ is the melt undercooling, and $J_{0}$ is the current density before nucleation, and $\Delta V$ is the nucleation volume, and $T_{\mathrm{m}}$ is the melting point, and $r$ is the spheroidal radius, and $k$ is a constant associated with the spherical coordinates, and $c$ is the mass heat capacity, and $\varepsilon$ is the correlation coefficient of electroconductivity. ${ }^{19-21}$

Figure 8 shows the cooling curves for the $\mathrm{Cu}-37.4 w / \% \mathrm{~Pb}$ monotectic alloys. With a calculation, the $\Delta T$ of $\mathrm{Cu}-\mathrm{Pb}$ monotectic alloy substantially increases from $44{ }^{\circ} \mathrm{C}$ to $159{ }^{\circ} \mathrm{C}$ due to the treatment of complex fields, which is attributed to the enhancement of the nucleation and the refinement of the crystal grains.

Under normal solidification, the phase segregation is strong, and lots of large blocks of $\mathrm{Pb}$ are observed (Figure 3a and 3b). The hardness difference between the $\mathrm{Pb}$ and the $\mathrm{Cu}-\mathrm{Pb}$ alloy is considerable, which results in the obviously inhomogeneous distribution of the microhardness (Table 1). The improvement of the microhardness, due to the treatment of complex fields, results in the solution strengthening. The solid solubility of $\mathrm{Pb}$ in $\mathrm{Cu}$ is considerably increased. Furthermore, intense pulse results in the refinement of the crystal grains, which is attributed to the homogeneous distribution of the microhardness (Table 1).

The dissolution of $\mathrm{Pb}$ in the $\mathrm{Cu}$ matrix promotes the lubrication effect of the $\mathrm{Cu}-\mathrm{Pb}$ alloy. Furthermore, the suppression of the phase separation and the refinement of crystals are beneficial to the wear resistance. Under the normal solidification, phase segregation is strong and the grains are coarse, where the friction coefficient is high and the amplitude of the friction coefficient is large (Figure 6). However, under the complex fields, the improvement of the microhardness and the refinement of crystals result in a considerably decrease of the friction coefficient and a small amplitude of the friction coefficient (Figure 6). Thus, the wear resistance of the alloy is greatly improved (Table 2).

\section{CONCLUSIONS}

1) Under normal solidification, phase segregation in the $\mathrm{Cu}-\mathrm{Pb}$ monotectic alloy is strong, and the crystal grains are coarse, which leads to a low microhardness and poor wear resistance.

2) Under the intense pulse and electromagnetic complex fields, the phase separation in the $\mathrm{Cu}-\mathrm{Pb}$ monotectic alloy is considerably suppressed, and the crystals are refined. The crystal grains radiationally grow from the guiding center to the surrounding area due to the gyroscopic motion caused by the Lorentz force.

3 ) Under the same friction condition, the hardness is considerably increased by $64.93 \%$, and the weight loss of the $\mathrm{Cu}-\mathrm{Pb}$ alloy prepared by the complex fields is substantially reduced by $51.5 \%$, which indicates that the wear resistance is greatly improved.

\section{Acknowledgements}

This project was financially supported by the National Natural Science Foundation of China (Grant No. 51561001) and the State Key Laboratory of Special Rare Metal Materials.

\section{REFERENCES}

${ }^{1}$ L. Ratke, S. Diefenbach, Liquid immiscible alloys, Materials Science \& Engineering R: Reports, 15 (1995) 7-8, 263-347, doi:10.1016/ 0927-796x(95)00180-8

${ }^{2}$ Gouthama, G. B. Rudrakshi, S. N. Ojha, Spray forming and wear characteristics of liquid immiscible alloys, Journal of Materials Processing Technology, 189 (2007) 1-3, 224-230, doi:10.1016/ j.jmatprotec.2007.01.026

${ }^{3}$ K. X. Song, Y. J. Zhou, P. F. Zhao, Y. M. Zhang, N. Bai, $\mathrm{Cu}-10 \mathrm{Sn}-4 \mathrm{Ni}-3 \mathrm{~Pb}$ alloy prepared by crystallization under pressure: An experimental study, Acta Metallurgica Sinica, 26 (2013) 2, 199-205, doi:10.1007/s40195-012-0118-0

${ }^{4}$ L. F. Kolesnichenko, O. I. Fushchich, L. D. Ignatenko, A. Yu. Talochka, S. V. Chernyauskas, Structure formation in the $\mathrm{Cu}-\mathrm{Sn}-\mathrm{Pb}$ system during sintering, Translated from Poroshkovaya Metallurgiya, 5 (1986) 281, 28-34, doi:10.1007/BF00813949

${ }^{5}$ Y. Liu, J. J. Guo, Y. Q. Su, H. S. Ding, J. Jia, Microstructures of rapidly solidified Al-In immiscible alloy, Transactions of Nonferrous Metals Society of China, 11 (2001) 1, 84-89, doi:10.1034/j.16000692.2001.300107. X

${ }^{6}$ Y. F. Wang, H. Y. Gao, Y. F. Hana, Y. B. Dai, J. Wang, B. D. Sun, First-principles study on the solubility of iron in dilute $\mathrm{Cu}-\mathrm{Fe}-\mathrm{X}$ alloys, Journal of Alloys and Compounds, 691 (2016), 992-996, doi:10.1016/j.jallcom.2016.08.247

${ }^{7}$ P. Terizieff, R. Luck, Magnetic investigations in liquid Al-In. Journal of Alloys and Compounds, 360 (2003) 1-2, 205-209, doi:10.1016/s0925-8388(03)00347-5

${ }^{8}$ O. V. Abramov, N. A. Bushe, T. F. Markova, D. Y. Chashechkina, $\mathrm{Al}-\mathrm{Pb}$ antifriction alloys produced under conditions of compensation of gravitational segregation by electromagnetic forces, Metal Science \& Heat Treatment, 24 (1982) 4, 239-243, doi:10.1007/BF00772466

${ }^{9}$ E. G. Wang, L. Zhang, X. W. Zuo, et al. Morphology of the Cu-rich Phase in $\mathrm{Cu}-\mathrm{Pb}$ Hypermonotectic Alloys under an Intense Magnetic Field, Steel Research International, 78 (2007) 5, 386-390, doi:10.1002/srin.200705908

${ }^{10}$ Y. Liu, Y. X. Li, J. J. Guo, Liquid phase separating mechanism and preparation techniques of immiscible alloys. Transactions of Nonferrous Society of China, 12 (2002) 3, 357-365, doi:10.1179/ 136217102225002655 
${ }^{11}$ W. X. Hao, G. C. Yang, H. Xie, Solidification behavior and microstructure of deep supercooled cu-37.4\% $\mathrm{Pb}$ monotectic alloy, Foundry Technology, 25 (2004) 2, 105-107, doi:10.3969/j.issn. 1000-8365.2004.07.022

${ }^{12}$ M. Zhu, M. Q. Zeng, Y. Gao, Microstructure and wear properties of $\mathrm{Al}-\mathrm{Pb}-\mathrm{Cu}$ alloys prepared by mechanical alloying, Wear, 253 (2005) 7, 832-838

${ }^{13}$ B. Majumdar, K. Chattopadhyay, Aligned monotectic growth in unidirectionally solidified $\mathrm{Zn}$-Bi alloys, Metallurgical and Materials Transactions A (Physical Metallurgy and, Materials Science), 31 (2000), 1833-1842, doi:10.1007/s11661-006-0245-1

${ }^{14}$ S. T. Ashok, T. V. Rajan, Bearing characteristics of cast leaded aluminium-silicon alloys, Wear, 197 (1996), 105-114, doi:10.1016/ 0043-1648(95)06861-9

${ }^{15}$ J. B. Andrews, A. C. Sandlin, R. A. Merrick, Directional solidification in immiscible systems: The influence of gravity, Advances in Space Research, 11 (1991), 291-295, doi:10.1016/0273-1177(91) 90298-X

${ }^{16}$ A. Kamio, S. Kumai, H. Tezuka, Solidification structure of monotectic alloys, Materials Science \& Engineering A, 146 (1991) 1-2, 105-121, doi:10.1016/0921-5093(91)90271-N

${ }^{17}$ Z. A. Tian, L. L. Zhou, Y. F. Mo, Y. C. Liang, R. S. Liu, Cooling rate dependence of polymorph selection during rapid solidification of liquid metal zinc, Transactions of Nonferrous Metals Society of China, 25 (2015) 12, 4072-4079, doi:10.1016/S1003-6326(15) 64057-2
${ }^{18}$ Z. J. Yan, J. Yan, Y Hu, et al, Crystallization in Zr60A115Ni25bulk metallic glass subjected to rolling at room temperature, Science in China Series E: Technological Sciences, 53 (2010) 1, 278-283, doi:10.1007/s11431-009-0315-x

${ }^{19}$ J. Z. Zhao, L. Ratke, B. Feuerbacher, Microstructure evolution of immiscible alloys during cooling through the miscibility gap, Modelling and Simulation in Materials Science, 6 (1998) 2, 123-139, doi:10.1088/0965-0393/6/2/003

${ }^{20}$ D. A. Da, W. S. Jiang, A New Method for Procession Monotectic Alloys under Simulated Microgravity Condition Using Electro-Magnetic Field on Earth. 4th International Conference on Experimental Methods for Microgravity Materials Science Research, California, 1992

${ }^{21}$ J. Y. Xu, S. X. Jin. Physic of plasma. Beijing: atomic energy press, 1981, 63-70

${ }^{22} \mathrm{C}$. Y. Ban, Fundamental study on solidification of Al alloys under electromagnetic fields, Northeastern University, 2002

${ }^{23}$ M. Zhang, Study solidification microstructure characteristics of Fe-Based alloys subjected to pulsed electric current treatment, Yanshan University, 2006

${ }^{24}$ J. P. Barnak, A.F. Sprecher, H. Conrad. Colony (grain) Size Reduction in Eutectic $\mathrm{Pb}-\mathrm{Sn}$ Castings by Electroplusing, Scripta Metallurgica Et Materialia, 32 (1995) 6, 879-884, doi:10.1016/0956716X(95)93218-S

${ }^{25}$ Y. H. Zhou, Z. Q. Hu, W. Q. Jie, Solidification technology, Beijing: machinery industry press, 1998 